\title{
Multidrug Resistance Inhibition
}

National Cancer Institute

\section{Source}

National Cancer Institute. Multidrug Resistance Inhibition. NCI Thesaurus. Code C40818.

Multidrug Resistance Inhibition involves interference with, or restraint of, the activities of biologic molecules or complexes involved in processes that increase the ability of cancer cells to counteract, defeat, or withstand the effects of multiple chemotherapeutic agents. Mechanisms involve decreased expression of multidrug efflux pumps ( $p$ glycoprotein), altered glutathione metabolism, increased topoisomerase II activity, and changes in various cellular proteins. Inhibition results in increased transport of drug into, or decreased transport out of, cells and increased effectiveness of chemotherapeutic agents. 